\title{
Penerapan Model Pembelajaran Inquiri Terbimbing Sebagai Upaya Meningkatkan Prestasi Belajar Matematika Siswa SMP
}

\author{
Luh Putu Eka Marhaeni Wraswati \\ SMP Negeri 2 Singaraja \\ Email:marhaeniwraswati@gmail.com
}

\begin{abstract}
Abstrak
Penelitian ini dilaksanakan di Kelas IX-7 SMP Negeri 2 Singaraja pada semester genap tahun pelajaran 2017/2018, dengan kondisi rata-rata prestasi belajar matematika hanya 59,5. Kondisi ini belum memenuhi KKM dan persentase ketercapaian KKM adalah 28,94\%. Tujuan penelitian ini adalah untuk mengetahui efektivitas penerapan Model Pembelajaran Inquiri Terbimbing dapat meningkatkan prestasi belajar matematika. Data penelitian dikumpulkan melalui tes prestasi belajar dan hasil tes dianalisis secara deskriptif kuantitatif. Data disajikan dalam bentuk rata-rata prestasi belajar dan persentase ketuntasan belajar. Penerapan model pembelajaran Inquiri Terbimbing secara positif dapat meningkatkan prestasi belajar matematika. Skor ratarata awal prestasi belajar siswa adalah 59,51 dengan ketuntasan belajar hanya 28,94\%, selanjutnya setelah pelaksanaan Siklus I meningkat rata-ratanya menjadi 75,36 dengan ketuntasan belajar mencapai 55,26 \%. Dari Siklus I ke Siklus II terjadi juga peningkatan yakni 78,29 dan ketuntasan belajar 86,84\%. Kesimpulan yang diperoleh bahwa Penerapan Model Pembelajaran Inquiri Terbimbing dapat meningkatkan prestasi belajar matematika.

Kata Kunci ; Model Pembelajaran, Inquiri Terbimbing, Prestasi Belajar
\end{abstract}

\begin{abstract}
This research was conducted in Class IX-7 of SMP Negeri 2 Singaraja in the even semester of the academic year 2017/2018, with an average condition of mathematics learning achievement of only 59.5. This condition did not meet the KKM and the KKM achievement percentage was $28.94 \%$. The purpose of this study was to determine the effectiveness of the application of the Guided Inquiry Learning Model to improve mathematics learning achievement. Research data were collected through learning achievement tests and test results were analyzed descriptively quantitatively. Data is presented in the form of average learning achievement and percentage of mastery learning. The application of Guided Inquiry learning models can positively improve mathematics learning achievement. The initial average score of student learning achievement was 59.51 with mastery learning only $28.94 \%$, then after the implementation of Cycle I increased the average to 75.36 with mastery learning reaching $55.26 \%$. From Cycle I to Cycle II there was also an increase of 78.29 and $86.84 \%$ mastery learning. The conclusion obtained is that the Implementation of Guided Inquiry Learning Model can improve mathematics learning achievement.
\end{abstract}

Keywords ; Learning Models, Guided Inquiry, Learning Achievement

\section{Pendahuluan}

Matematika merupakan ilmu universal yang mendasari perkembangan teknologi modern, yang mempunyai peran penting dalam berbagai disiplin dan memajukan daya pikir manusia. Istilah matematika berasal dari perkataan latin mathematica, yang mulanya berasal dari perkataan Yunani mathematike, yang secara etimologis menurut Elea Tinggih (dalam Suherman, 2003: 16) mengatakan bahwa "perkataan matematika berarti ilmu pengetahuan yang diperoleh dengan bernalar" dalam hal ini matematika lebih menekankan pada penalaran, bukan dari hasil observasi ataupun hasil eksperimen. Dengan demikian maka dapat dikatakan bahwa matematika adalah ilmu yang didapatkan melalui penalaran dan pola pikir serta hubungan, suatu jalan atau pola berpikir, suatu seni, suatu bahasa, dan suatu alat yang didasari oleh logika untuk mengembangkan kemampuan berpikir.

Dalam belajar matematika seorang guru harus mampu mengupayakan untuk menanamkan konsep-konsep matematika yang tertuang pada setiap pokok bahasan yang ada kepada siswa sebagai sebuah proses dalam belajar. Bruner (Suherman, 2003: 43) mengatakan, belajar matematika akan lebih berhasil jika proses pengajaran diarahkan kepada konsep-konsep dan struktur-struktur yang termuat dalam pokok bahasan yang diajarkan serta anak sebaiknya diberi kesempatan untuk memanipulasi benda-benda (alat peraga) serta dalam proses belajar anak melewati 3 tahap yaitu; Tahap enaktif, dalam tahap ini anak secara langsung terlibat dalam memanipulasi objek. Tahap ikonik, dalam tahap ini kegiatan yang dilakukan anak berhubungan dengan mental, yang merupakan gambaran dari objek yang dimanipulasinya. Tahap simbolik, dalam tahap ini anak memanipulasi lambang atau simbol dari objek tertentu.

Kondisi yang ada di lapangan adalah ketidakmampuan guru untuk melaksanakan pembelajaran dengan strategi-strategi, teknik-teknik yang mampu melibatkan siswa dalam proses pembelajaran, sehingga pembelajaran terarah kepada peningkatan prestasi belajar siswa. Kemalasan guru dalam mengkaji serta merefleksi kualitas pembelajaran mereka di kelas sebagi penyebab utama, serta keengganan melaksanakan inovasi merupakan penguat kondisi pembelajaran kita saat ini. Untuk mengatasi hal-hal ini maka guru semestinya mampu memanfaatkan model-model pembelajaran sesuai dengan karakteristik mata pelajaran, mampu memotivasi siswa untuk secara maksimal mengikuti proses pembelajaran, sehingga secara serta merta dapat meningkatkan prestasi belajarnya. 
Pembelajaran matematika pada kelas IX-7 SMP Negeri 2 Singaraja, hasilnya belum memenuhi kriterria ketuntasan minimal (KKM). Berdasarkan penelitian awal yang dilaksanakan bulan Januari 2018, diperoleh hasil berupa rata-rata nilai siswa adalah; 59,51 dengan ketuntasan belajar 28,94\% artinya dari sejumlah 38 siswa kelas IX-7 ternyata yang berhasil mencapai KKM (tuntas) baru 11 orang, dengan KKM 75.

Melihat permasalahan tersebut, perlu kiranya dilakukan perbaikan metode pembelajaran. Salah satunya adalah menggunakan strategi pembelajaran Inquiri terbimbing. Rumusan masalah penelitian ini adalah apakah penerapam model pembelajaran Inquiri Terbimbing dapat meningkatkan prestasi belajar matematika siswa kelas IX-7 SMP Negeri 2 Singaraja. Penanggulangan permasalahan ini, melalui penerapan model pembelajaran Inquiri Terbimbing. Penerapan model ini diyakini akan dapat menanggulangi permasalahan karena model ini mamiliki keunggulan-keunggulan seperti: (1)Membantu siswa dalam mengembangkan kognitif siswa. (2) Membangkitkan gairah pada siswa, (3)Memberi kesempatan pada siswa untuk bergerak maju sesuai dengan kemampuan. (4)Membantu memperkuat pribadi dan kepercayaan diri siswa. (5)Model ini berpusat pada anak, ( 6 ) Guru menjadi teman belajar.

Tujuan penelitian ini adalah untuk mengetahui seberapa besar terjadinya peningkatan keterampilan prestasi belajar matematika siswa setelah mengikuti pembelajaran matematika dengan menggunakan model pembelajaran Inquiri Terbimbing. Penelitian ini diharapkan bermanfaat bagi siswa, dapat meningkatkan kualitas pembelajaran sehingga, sehingga KKM dapat tercapai. Bagi Guru mata pelajaran matematika, bermanfaat untuk dapat meningkatkan kompetensi guru dalam mengatasi masalah pembelajaran di kelas. Bagi sekolah, memperkaya model dan strategi pembelajaran dalam praktiknya untuk meningkatkan kualitas output sekolah.

\section{Metode}

Penelitian tindakan kelas ini, menggunakan rancangan penelitian menurut Depdiknas 2011: 12. Subjek penelitian ini adalah semua siswa kelas IX-7 SMP Negeri 2 Singaraja dan objek penelitian ini adalah peningkatan prestasi belajar siswa. Penelitian ini dilakukan selama 3 bulan yakni; dari bulan Januari 2018 sampai bulan Maret 2018.

Untuk mengumpulkan data penelitian ini digunakan tes prestasi belajar, dengan pelaksanaannya setiap akhir pertemuan melalui posttest. Test prestasi yang digunakan adalah sesuai dengan instrumen yang telah disusun pada RPP. Metode yang digunakan untuk menganalisis data hasil penelitian ini adalah metode deskriptif kuantitatif, dengan memberi komentar-komentar mengklasifikasikan data, dan selanjutnya membuat kesimpulan refleksi dengan mencari makna dari kesimpulan hubungan antar kategori. Indikator keberhasilan penelitian ini yakni; bila secara individu telah mencapai sama dengan atau melebihi KKM yakni 75, dan secara klasikal ratarata ketuntasan belajar telah melebihi $85 \%$.

\section{Hasil dan Pembahasan}

Rendahnya prestasi belajar matematika, disebabkan oleh beberapa faktor yaitu: a) cara pengajaran guru masih konvensional, guru masih mendominasi pembelajaran sehingga peserta didik lebih banyak menunggu. Sedangkan yang diharapkan dalam pembelajaran adalah agar siswa yang aktif mencaritemukan masalah yang dipelajari; b) siswa tidak terbiasa untuk berusaha sendiri; c) materi yang disajikan tidak ada pengembangan; e) rumusan tujuan belum tepat sesuai kata-kata kerja operasional.

Implementasi model pembelajaran Inquiri Terbimbing, merupakan solusi permasalahan ini. Penelitian diawali dengan perencanaan dengan kegiatannya meliputi; Menyusun Rencana Pelaksanaan Pembelajaran (RPP), menentukan waktu pelaksanaan, meminta kepada teman-teman guru mata pelajaran sejenis sebagai mitra kesejawatan dalam observasi pembelajaran, menyusun instrumen penilaian prestasi belajar dan instrumen pedoman observasi pelaksanaan model pembelajaran Inkuiri Terbimbing.

Sesuai jadwal pelajaran, maka pelaksanaan pembelajaran matematika dengan mengimplementasikan model pembelajaran Inkuiri Terbimbing dilaksanakan di kelas IX-7. Pelaksanaan pembelajaran mengikuti standar proses pembelajaran yakni; tahap pembukaan, tahap kegiatan inti dan tahap kegiatan penutup. Pada kegiatan pembukaan dilaksanakan melalui (1) mengucapkan salam, (2) doa bersama sebelum kegiatan pembelajaran dimulai, (3) mengingatkan materi yang lalu melalui pertanyaan-pertanyaan dan mempersilahkan pada siswa untuk menyampaikan hasil tugas yang diberikan pada minggu sebelumnya, (4) menyampaikan KKM yang harus dicapai siswa, (5) mengaitkan antara materi sebelumnya dengan materi yang akan diajarkan, (6) menyampaikan materi yang akan diajarkan pada pertemuan kali ini yakni; Standar Kompetensi; Menentukan orientasi dan lokasi benda dalam koordinat kartesius serta menentukan posisi relative terhadap acuan tertentu. Pelaksanaan penelitian selama tiga kali pertemuan dengan Indikator pencapai kompetensi dasar tersebut adalah (1)Pertemuan I; Memahami daerah pada bidang kartesius dan memahami cara menggambarkan pasangan bilangan pada bidang kartesius. (2) Pertemuan II; Memahami hubungan antara daerah pada bidang kartesius dan memahami sifat titik pada bidang kartesius terhadap kuadrannya. (3) Pertemuan III; Menggambarkan titik pada bidang kartesius dan menentukan rumus jarak antara dua titik pada bidang kartesius.

Terkait dengan implementasi model pembelajaran Inquiri Terbimbing maka tahapan proses pembelajaran matematika dilaksanakan dengan tahapan atau sintaks kegiatan meliputi; (1) Tahap berhadapan dengan masalah. 
Pada kegiatan ini, siswa diberikan pertanyaan atau permasalahan yang disusun sedemikian rupa sehingga tidak mengakibatkan guru memberikan jawaban dari pertanyaan tersebut, melainkan mengarahkan atau membimbing siswa unruk menemukan jawabannya sendiri. Siswa dilatih untuk dapat memahami masalah. (2) Pengumpulan informasi. Setelah memahami masalah yang diberikan, siswa mengumpulkan informasi tentang masalah yang dihadapi selanjutnya dirumuskan untuk pemecahan masalah yang diberikan. (3) Pengumpulan data. Data atau informasi yang telah diperoleh pada tahap sebelumnya kemudian digunakan sebagai acuan untuk menentukan jawaban dari permasalahan yang telah diberikan. (4) Selanjutnya siswa melakukan diskusi untuk menganalisis dan menyelidiki permasalahan guna mendapatkan pemecahan masalah serta jawaban dari masalah yang telah diberikan. (5) Hasil diskusi tersebut kemudian dipresentasikan di depan kelas, siswa yang lain diberikan kesempatan untuk bertanya, menyampaikan pendapat atau masukan. (6) Analisis proses inquiri. Pada tahap ini siswa dibimbing untuk menganalisis hasil diskusi mengenai permasalahan yang diberikan, kemudian menarik suatu kesimpulan terhadap kegiatan yang telah dilakukan.

Yang dilakukan pada kegiatan observasi adalah; mencatat semua kegiatan yang terjadi, semua reaksi yang sudah dilakukan, menggunakan lembar observasi dalam upaya untuk mengetahui kesesuaian antara sintak perencanaan pembelajaran dengan pelaksanaan, mengetahui efektivitas waktu, kegiatan dan proses pelaksanaan, dan tes prestasi belajar dalam upaya untuk mengumpulkan data tentang efek implementasi model pembelajaran Inkuiri Terbimbing terhadap prestasi belajar siswa, serta sebagai bahan dalam membandingkan antara data hasil yang diperoleh dengan indikator keberhasilan penelitian. Observasi dilaksanakan bersamaan dengan pelaksanaan pembelajaran dengan menggunakan teman sejawat guru matematika sebagai observernya.

Refleksi terhadap hasil observasi yang telah dilaksanakan rata-rata yang diperoleh telah mencapai 75,36 dan ketuntasan belajar 55,26 \%. Sintesis terhadap pelaksanaan siklus I, adalah menyangkut Keberhasilan yang diperoleh siswa dengan menunjukkan hasil rata-rata 75,36 dan ketuntasan belajar 55,26 \%, hal ini menunjukkan bahwa dari 38 orang siswa subjek penelitian terdapat 21 orang siswa telah berhasil memperoleh nilai rata-rata diatas KKM (75). Selebihnya, terdapat 17 orang siswa yang belum mampu mencapai KKM, sehinga mereka perlu dibina kembali. Peningkatan prestasi belajar dari data awalnya rata-rata adalah; 59,51 dan ketuntasan belajar; 28,94 selanjutnya pada siklus I rata-rata prestasi belajar siswa menjadi75,36 dengan ketuntasan belajar; 55,26 tidak terlepas dari perencanaan, pelaksanaan dan observasi yang telah dilaksanakan.

Hasil penelitian siklus I ini jika dikonfirmasi dengan indikator keberhasilan penelitian ternyata penelitian ini belum dapat diketegorikan berhasil, karena pada bagian sebelumnya telah disampaikan indikator keberhasilan penelitian ini adalah jika nilai rata-rata prestasi belajar siswa telah mencapai minimal sama atau lebih dari KKM yang telah ditentukan, dan telah mencapai ketuntasan klasikal sebanyak 85. KKM yang ditentukan adalah 75 , sedangkan rata-rata prestasi belajar siswa yang diperoleh pada siklus I ini baru mencapai; 75,36 dan ketuntasan klasikal baru mencapai; 55,26. Dengan demikian maka pelaksanaan penelitian dilanjutkan pada siklus II.

Walaupun hasilnya belum memenuhi kriteria keberhasilan, namun pelaksanaan penelitian siklus I ini perlu dinilai keunggulan maupun kelemahannya. Berikut ini disampaikan keunggulan dan kelemahan siklus I ini. Keunggulan-keunggulan yang telah nampak dari pelaksanaan siklus I ini jika dibandingkan dngan proses pembelajaran sebelumnya adalah; (1) Siswa telah menguasai ketrampilan dan proses kognitif dalam memecahkan permasalahan yang diberikan, (2) Siswa mulai terbiasa kerja secara kelompok dan mampu menyajikan hasil diskusi atau kerja kelompoknya, (3) Gairah belajar pada siswa mulai meningkat, dapat dilihat dari persensi atau kehadiran siswa serta kemauan melaksanakan tugas-tugas yang dibebankan kepadanya, (4) Guru betul-betul sebagai teman belajar bagi siswa, dan siswa telah berani secara terbuka bertanya tentang permasalahan atau materi lainnya.

Kendala yang masih ada adalah beberapa siswa masih terpaku kepada pola pembelajaran lama, masih tercengang memikirkan kebiasaan yang lama dimana mereka masih senang untuk dijarkan materi pelajaran oleh gurunya, beberapa siswa belum terbiasa bertanya, berdiskusi, mengerjakan tugas-tugas atau memecahkan permasalahan, mempresentasikan hasil kerja kelompoknya. Disisi lain guru terkendala dalam merubah kebiasaan untuk tidak mengajarkan kepada siswa, tetapi melaksanakan kegiatan membelajarkan siswa sehingga kegiatan menceramahkan materi harus dikurangi.

Untuk menanggulangi kendala-kendala ini, pada siklus II guru lebih fokus kepada pembimbingan serta memotivasi munculnya segala bentuk aktivitas siswa melalui memberikan rangsangan-rangsangan berupa reward dan funihsment. Sedangkan kendala yang masih dihadapi oleh guru adalah diupayakan melalui pembiasaan dalam proses pembelajaran selalu memperhatikan tahapan-tahapan kegiatan pembelajaran sesuai model yang digunakan.

Dengan melihat semua hasil penelitian yang dicapai pada siklus I, baik refleksi data kualitatif maupun refleksi data kuantitatif, maka untuk perencanaan pelaksanaan penelitian di siklus II ini ada beberapa hal yang perlu dilakukan yaitu; penyempurnaan rencana pelaksanaan pembelajaran dan membuat instrumen pengumpulan data. Bersama guru mata pelajaran sejawat, merancang skenario penerapan pembelajaran dengan melihat kekurangan-kekurangan yang ada pada siklus I dengan mengidentifikasi hal-hal yang bisa dilakukan untuk peningkatan pembelajaran.

Pada hari yang sudah ditentukan sesuai jadwal, peneliti memulai tahap pelaksanaan tindakan dengan membawa semua persiapan yang sudah dibuat. Implementasi model pembelajaran Inkuiri Terbimbing sesuai 
dengan sintaksnya, dengan menanggulangi hal-hal yang masih menjadi kelemahan-kelemahan pada siklus sebelumnya. Hal ini dimaksudkan agar implementasi model ini pada siklus II dapat memperoleh hasil sesuai dengan harapan. Pada kegiatan pembukaan dilaksanakan melalui (1) mengucapkan salam, (2) doa bersama sebelum kegiatan pembelajaran dimulai, (3) mengingatkan materi yang lalu melalui pertanyaan-pertanyaan dan mempersilahkan pada siswa untuk menyampaikan hasil tugas yang diberikan pada minggu sebelumnya, (4) menyampaikan KKM yang harus dicapai siswa, (5) mengaitkan antara materi sebelumnya dengan materi yang akan diajarkan, (6) menyampaikan materi yang akan diajarkan pada pertemuan kali ini, (7) standar kompetensi yang harus dikuasai siswa yakni sistem persamaan linear dua variabel; Standar Kompetensi. (8) Kompetensi Dasarnya adalah Memilih srategi dan aturan yang sesuai untuk memecahkan masalah, menyelesaikan permasalahan nyata yang berkaitan dengan persamaan linear dua variabel, sistem persamaan linear dua varianel dan atau fungsi kuadrat, membuat dan menyelesaikan model matematika dari berbagai permasalahan nyata .

Pelaksanaan penelitian pada siklus II ini juga selama tiga kali pertemuan, dengan Indikator (1) pertemuan I; menyusun model matematika SPLDV berkaitan dengan masalah sehari-hari . (2) pertemuan II; menyelesaikan SPLDV. (3) pertemuan III; menyelesaikan masalah sehari-hari yang berkaitan SPLDV .

Terkait dengan implementasi model pembelajaran Inkuiri Terbimbing maka tahapan proses pembelajaran matematika dilaksanakan dengan tahapan atau sintaks kegiatan meliputi; (1)Tahap berhadapan dengan masalah. Pada kegiatan ini, siswa diberikan pertanyaan atau permasalahan yang disusun sedemikian rupa sehingga tidak mengakibatkan guru memberikan jawaban dari pertanyaan tersebut, melainkan mengarahkan atau membimbing siswa unruk menemukan jawabannya sendiri. Siswa dilatih untuk dapat memahami masalah. (2) Pengumpulan informasi. Setelah memahami masalah yang diberikan, siswa mengumpulkan informasi tentang masalah yang dihadapi selanjutnya dirumuskan untuk pemecahan masalah yang diberikan. (3) Pengumpulan data. Data atau informasi yang telah diperoleh pada tahap sebelumnya kemudian digunakan sebagai acuan untuk menentukan jawaban dari permasalahan yang telah diberikan. (4) Selanjutnya siswa melakukan diskusi untuk menganalisis dan menyelidiki permasalahan guna mendapatkan pemecahan masalah serta jawaban dari masalah yang telah diberikan. (5) Hasil diskusi tersebut kemudian dipresentasikan di depan kelas, siswa yang lain diberikan kesempatan untuk bertanya, menyampaikan pendapat atau masukan. (6) Analisis proses inquiri. Pada tahap ini siswa dibimbing untuk menganalisis hasil diskusi mengenai permasalahan yang diberikan, kemudian menarik suatu kesimpulan terhadap kegiatan yang telah dilakukan.

Observasi dilaksanakan dengan mencatat semua kegiatan yang terjadi, semua reaksi yang sudah dilakukan, menggunakan lembar observasi dalam upaya untuk mengetahui kesesuaian antara sintak perencanaan pembelajaran dengan pelaksanaan, mengetahui efektivitas waktu, kegiatan dan proses pelaksanaan, dan tes prestasi belajar dalam upaya untuk mengumpulkan data tentang efek implementasi model pembelajaran Inkuiri Terbimbing terhadap prestasi belajar siswa, serta sebagai bahan dalam membandingkan antara data hasil yang diperoleh dengan indikator keberhasilan penelitian.

Hasil observasi selanjutnya dianalisis secara kuantitatif dan diperoleh Rata-rata hasil tes prestasi belajar siswa adalah 78,29 dan ketuntasan belajar klasikalnya adalah; 86,84\%. Nilai rata-rata yang diperoleh pada siklus II menunjukkan peningkatan sebanyak 5,63. Ketuntasan klasikal juga terjadi peningkatan sebanyak 36,58\%. Dari sejumlah 38 orang subjek penelitian ini ditemukan 33 orang siswa yang sudah mampu memperoleh nilai rata-rata prestasi belajar diatas KKM, dan masih sebanyak 5 orang siswa yang memperoleh nilai rata-rata prestasi belajar dibawah KKM. Secara keseluruhan hasil yang didapat telah memenuhi kriteria keberhasilan penelitian sehingga tidak diteruskan lagi ke siklus berikutnya.

Setelah pelaksanaan tindakan dan berdasarkan fakta yang diperoleh melalui observasi, maka penilaian terhadap pelaksanaan siklus II dapat disampaikan bahwa; Perencanaan siklus II yang sudah dilaksanakan secara matang, dengan membuat RPP sesuai alur Inkuiri Terbimbing lebih menuntun siswa mampu meningkatkan kemampuan belajarnya. Pada saat pelaksanaan tindakan, peneliti telah mengupayakan agar alur Inkuiri Terbimbing berjalan sesuai harapan sehingga siswa betul belajar sesuai harapan model pembelajaran ini. Pengamatan/observasi juga sudah berjalan sesuai harapan walaupun hasilnya belum sempurna.

Hasil penelitian telah memenuhi indikator keberhasilan penelitian yakni; ditentukan bahwa indikator keberhasilan penelitian ini adalah telah mencapai nilai rata-rata prestasi belajar minimal sama dengan KKM atau lebih, dan ketuntasan belajar secara klasikal telah mencapai $85 \%$. Sedangkan sesuai dengan hasil yang diperoleh bahwa rata-rata prestasi belajar siswa telah mencapai 78,29 dan ketuntasan belajar secara klasikal telah mencapai 86,84\%. Terdapat lima orang siswa yang memperoleh nilain kurang dari KKM disebabkan oleh adanya kemampuan siswa dimaksud memang perlu bimbingan secara khusus.

Hasil tes prestasi belajar di siklus I telah menemukan efek utama bahwa penggunaan metode tertentu akan berpengaruh terhadap prestasi belajar siswa yang dalam hal ini adalah metode inquiri terbimbing. Hal ini sesuai dengan hasil meta analisis metode pembelajaran yang dilakukan oleh Soedomo (1989/1990) yang menyatakan bahwa metode pembelajaran yang diterapkan oleh seorang guru berpengaruh terhadap prestasi belajarnya.

Seperti telah diketahui bersama bahwasannya mata pelajaran matematika menitik beratkan pembelajaran pada aspek kognitif, afektif, dan psikomotor sebagai pedoman prilaku kehidupan sehari-hari siswa. Untuk penyelesaian kesulitan yang ada maka penggunaan metode ini dapat membantu siswa untuk berkreasi, bertindak 
aktif, bertukar pikiran, mengeluarkan pendapat, bertanya, berdiskusi, berargumentasi, bertukar informasi dan memecahkan masalah yang ada bersama dengan anggota kelompok diskusinya. Hal inilah yang membuat siswa berpikir lebih tajam, lebih kreatif dan kritis sehingga mampu untuk memecahkan masalah-masalah yang kompleks dan efek selanjutnya adalah para siswa akan dapat memahami dan meresapi mata pelajaran matematika lebih jauh.

Kendala yang masih tersisa yang perlu dibahas adalah prestasi belajar yang dicapai pada siklus I ini belum memenuhi harapan sesuai dengan kriteria keberhasilan penelitian yang diusulkan pada mata pelajaran matematika di sekolah ini yaitu 75 secara individual dan ketuntasan klasikal 85. Oleh karenanya upaya perbaikan lebih lanjut masih perlu diupayakan sehingga perlu dilakukan perencanaan yang lebih matang untuk siklus selanjutnya.

Hasil yang diperoleh dari tes prestasi belajar di siklus II menunjukkan bahwa kemampuan siswa dalam mengikuti pelajaran sudah cukup baik. Ini terbukti dari rata-rata nilai siswa mencapai 78,29 dengan ketuntasan klasikal adalah 86,84. Hasil ini menunjukkan bahwa metode inquiri terbimbing telah berhasil meningkatkan kemampuan siswa menempa ilmu sesuai harapan. Inquiri terbimbing merupakan model yang cocok bagi siswa apabila guru menginginkan mereka memiliki kemampuan berkreasi, berargumentasi, mengeluarkan pendapat secara lugas, bertukar pikiran, berargumentasi, mengingat penggunaan metode ini adalah untuk memupuk kemampuan berbicara dihadapan orang banyak.

Setelah dibandingkan nilai awal, nilai siklus I dan nilai siklus II, terjadi kenaikan yang signifikan, baik pada rata-rata maupun pada ketuntasan belajar. Kenaikan ini tidak bisa dipandang sebelah mata karena kenaikan nilai ini adalah dari upaya yang maksimal yang dilaksanakan peneliti demi peningkatan mutu pendidikan dan kemajuan pendidikan khususnya di SMP Negeri 2 Singaraja. Keberhasilan implementasi model pembelajaran inkuiri terbimbing tidak lepas dari keunggulan model dimaksud. Suryobroto (2002: 201) menyebutkan kelebihan inkuiri terbimbing (guide inquiry) antara lain; (1) Membantu siswa dalam mengembangkan atau memperbanyak persediaan dan penguasaan ketrampilan dan proses kognitif siswa. (2) Membangkitkan gairah pada siswa, misalkan siswa merasakan jerih payah penyelidikannya, menemukan keberhasilan dan kadang-kadang kegagalan. (3) Memberi kesempatan pada siswa untuk bergerak maju sesuai dengan kemampuan. (4) Membantu memperkuat pribadi siswa dengan bertambahnya kepercayaan pada diri sendiri melalui proses-proses penemuan. (5) Model ini berpusat pada anak, misalkan memberi kesempatan kepada mereka, dan guru berpartisipasi sebagai teman belajar dalam mengecek ide. (6) Guru menjadi teman belajar, terutama dalam situasi penemuan yang jawabanya belum diketahui.

Sebagai dasar mengetahui perkembangan hasil penelitian ini maka berikut ini disajikan rekapitulasi hasil sesuai dengan tabel berikut;

Tabel 1. Rekapitulasi perkembangan nilai matematika

\begin{tabular}{llll}
\hline Aspek & Awal & Siklus I & Siklus II \\
\hline Rata-Rata & 59,51 & 75,36 & 78,29 \\
Ketuntasan & 28,94 & 55,26 & 86,84 \\
\hline
\end{tabular}

Sumber: Data Hasil Perhitungan 2018

Selanjutnya rekap hasil penelitian tersebut jika disajikan dengan grafik maka akan terlihat seperti gambar berikut.

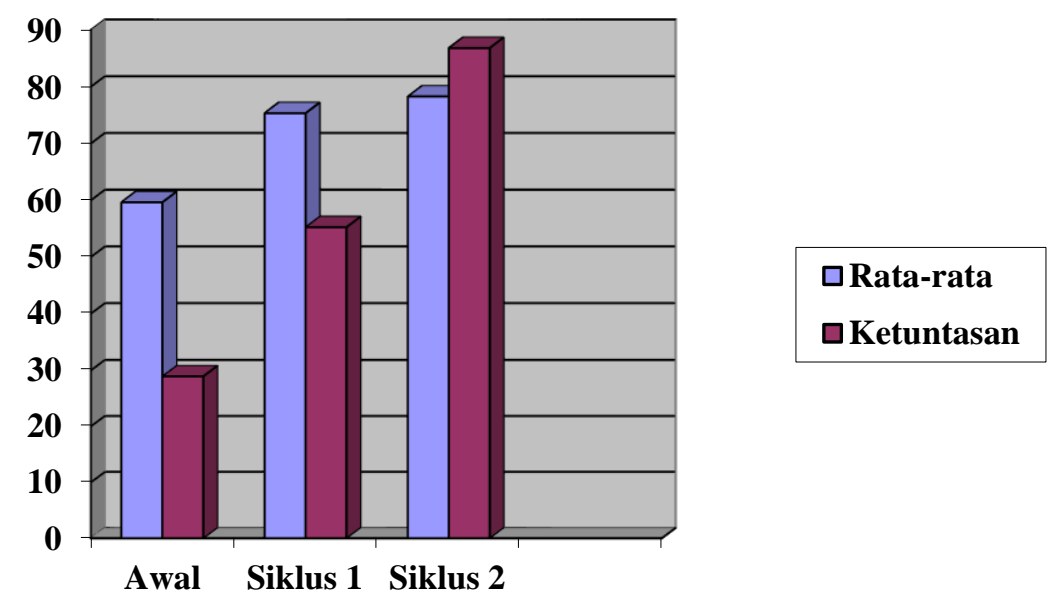

Gambar 1. Grafik Perkembangan hasil penelitian

\section{Simpulan}

Dari semua data pendukung pembuktian pencapaian tujuan pembelajaran dapat disampaikan simpulan penelitian ini adalah bahwa model Inquiri Terbimbing dapat memberi jawaban yang diharapkan sesuai tujuan penelitian ini. Semua ini dapat dicapai adalah akibat kesiapan dan kerja keras peneliti dari sejak pembuatan 
proposal, review hal-hal yang belum bagus bersama teman-teman guru, penyusunan kisi-kisi dan instrumen penelitian, penggunaan sarana trianggulasi data sampai pada pelaksanaan penelitian yang maksimal.

Berdasarkan temuan yang sudah disimpulan dari hasil penelitian, dalam upaya mencapai tujuan pembelajaran matematika, dapat disampaikan saran-saran bagi guru dalam melaksanakan proses pembelajaran pada mata pelajaran matematika, penggunaan model Inquiri Terbimbing semestinya menjadi pilihan dari beberapa metode yang ada mengingat metode ini telah terbukti dapat meningkatkan kerjasama, berkreasi, bertindak aktif, bertukar informasi, mengeluarkan pendapat, bertanya, berdiskusi, berargumentasi dan lain-lain. Walaupun penelitian ini sudah dapat membuktikan efek utama dari model Inkuiri Terbimbing dalam meningkatkan prestasi belajar, sudah pasti dalam penelitian ini masih ada hal-hal yang belum sempurna dilakukan, oleh karenanya kepada peneliti lain yang berminat meneliti topik yang sama untuk meneliti bagian-bagian yang tidak sempat diteliti. Selanjutnya untuk adanya penguatan-penguatan, diharapkan bagi peneliti lain untuk melakukan penelitian lanjutan guna verifikasi data hasil penelitian.

\section{Daftar Pustaka}

Arikunto, Suharsimi; Suhardjono; Supardi. 2006. Penelitian Tindakan Kelas. Jakarta: PT Bumi Aksara. Direktorat Tenaga Kependidikan, Direktorat Jendral Peningkatan Mutu Pendidik dan Tenaga Kependidikan. 2008. Metode dan Teknik Supervisi. Jakarta: Depdiknas.

Depdiknas. 2002. Contextual Teaching And Learning. Jakarta: Dirjen Pendidikan Dasar dan Menengah.

Depdiknas. 2011. Membimbing Guru dalam Penelitian Tindakan Kelas. Jakarta: Pusat Pengembangan Tenaga Kependidikan Badan Pengembangan Sumber Daya Manusia Pendidikan Penjaminan Mutu Pendidik.

Dahar, Ratna Wilis. 1989. Teori-Teori Belajar. Jakarta: Penerbit Erlangga.

Surya, Mohammad. 2004. Psikologi Pembelajaran dan Pengajaran. Bandung: Pustaka Bani Quraisy.

Sriyono. 1992. http://www.scribd.com/doc/9037208/ 